\title{
INFLUENCE OF DEEP CRYOGENIC TREATMENT AT ABRASIVE WEAR RESISTANCE IN ASTM 743 CA6NM
}

\author{
A. F. Hernandez, \\ C. R. M. Silva, \\ J. A. Araujo, \\ ABSTRACT \\ and J. D. B. de Mello \\ The Deep Cryogenic Treatment (DCT) has been used for improvement of \\ steel mechanical properties, basically the abrasive wear resistance. At this \\ work the cryogenic treatment at $-190^{\circ} \mathrm{C}$ for 20 hours was applied, after \\ conventional heat treatment, to improve its abrasive wear resistance. The \\ specimens, divided in two groups, had been austenitized for forty five \\ minutes at $965^{\circ} \mathrm{C}$ and $1065^{\circ} \mathrm{C}$, respectively, then quenched in oil at room \\ temperature. Afterwards they were tempered at $565^{\circ} \mathrm{C}$ for 90 minutes, and \\ then cooled in air. Subsequently some samples were treated cryogenically, \\ and some of them were submitted to a new cycle of tempering at $565^{\circ} \mathrm{C}$ for \\ 90 minutes. The performed experiment included: hardness brinell, $\mathrm{X}$ - \\ raydifratometry, metallography and micro-abrasive wear test. Variations in \\ the microstructure with an improvement in the abrasive wear coefficient \\ were found. These variations are probably a positive effect of the DCT on \\ the samples microstructure. The microstructure were transformed from \\ blocks of parallel lath martensite to small parallel or almost parallel \\ packages of fine needles forming austenite. Traces of previous or retained \\ austenite were found delimiting the grains. It is presumed that micro-carbide \\ homogeneously distributed in the matrix and in the grain's contours of the \\ Received: September 29, 2012 \\ retained austenite was formed. \\ Revised: October 28, 2012 \\ Accepted: November 28, 2012 \\ Keywords: Cryogenic, ASM 743 CA6NM, abrasive wear resistance
}

\section{NOMENCLATURE}

$\begin{array}{ll}\mathrm{a} & \text { constant } \\ \mathrm{b} & \text { Burgers's vector } \\ (\bar{D}) & \text { martensite packet size } \\ \mathrm{d} & \text { martensite width } \\ \mathrm{d} & \text { diameter, mm } \\ \mathrm{G} & \text { shear modulus of steel } \\ \mathrm{h} & \text { height, mm } \\ K_{y} & \text { constant depending on the content of Ni and Mn } \\ & \text { steel } \\ K_{s} & \text { correlation type Hall-Petch } \\ K & \text { laths } \\ \mathrm{C} & \text { percentage of carbon steel, \% } \\ \theta & \text { degree of disorientation among the contours of } \\ & \text { the laths, degrees }\end{array}$

\section{Greek symbols}

$\begin{array}{ll}\pi & \text { pi } \\ \sigma_{0} & \text { frictional stress of iron } \alpha \\ \sigma_{1} & \text { solid solution hardening due to } \mathrm{Mn} \\ \rho_{0} & \text { density of dislocations }\end{array}$

\section{INTRODUCTION}

New materials and thermal treatments are continuously developed in order to resist aggressive environments at chemistry, oil and energy generation industry. With alloys additions and reduction of carbon percentage at steels, is possible to reduce probability of $\mathrm{Cr} 23 \mathrm{C} 6$ formation, responsible for inter-granular fragility (Newman, 2001).Therefore, a middle alloy steel A 743 CA6NM with composition 0.06 wt $\% \mathrm{C}, 12.5 \mathrm{wt} \% \mathrm{Cr}$ and $4.5 \mathrm{wt} \% \mathrm{Ni}$ was developed, aiming application for electric industry.

Previous research about influence of deep cryogenic treatment at general steel properties has been reported, but just a few papers aim efforts to identify cryogenic micromechanism. They are related to high retained austenite reduction and increase of complex ultrafine carbides fraction, precipitated at martensite matrix (<http://www.falkbrok.se/tabeller/ stainless_heat_resistent_steel.htm $>$, acess: 02 Feb. 2008).

This is a complex diffusionless phase transformation and for low atoms mobility, the carbides precipitation onto cryogenics temperatures near to $-196^{\circ} \mathrm{C}$ has been almost unknown. The early formation of the stoichiometric transition carbides Fe2C (carbide- $\eta$ ), at this temperature had been studied between 1980 and 1990. A mechanism that allow the carbon atoms to leave its originals interstitials positions in the iron tetragonal structure had been identified, where the carbide- $\eta$ adopts an orthorhombic structure (Barron, 1982 and 1990).

Meng et al research (Meng et al., 1994) explained that a continuous temperature decrease improve the martensite energy deformation, increasing its instability and probably affecting the discordance structure in the way that crystalline parameters contraction of the iron occurs in different 
forms. The carbons atoms will be forced out of its positions where they will form a transition carbide structure within submicroscopic size. Those structures formed in large amount at martensite matrix will act like nucleus for the stables fines carbides formation. Hence, is reasonable to deduce that the same energy could act upon the martensite refinement (Meng et al., 1994).

\section{EXPERIMENTS}

\section{Heat Treatment}

In this work six heat treatment conditions were specified in which the martensite steel grade CA6NM was conducted, in combination with a DCT and two different austenitizing temperatures, to identify the influence in wear resistance. In Table 1 different thermal treatment applied to the martensitic stainless steel studied at this research are shown.

Table 1. Cycles of thermal treatment applied to ASTM 743 CA6NM.

\begin{tabular}{|c|c|c|}
\hline Cycles & $\begin{array}{c}\text { No. of } \\
\text { samples }\end{array}$ & Heat Treatment Guideline \\
\hline I & 6 & $\begin{array}{l}\text { Austenitization (A) at } 965^{\circ} \mathrm{C} \\
\text { during } 45 \text { min., tempering }(\mathrm{T}) \\
\text { at } 565^{\circ} \mathrm{C} \text { during } 90 \mathrm{~min} \text {. }\end{array}$ \\
\hline II & 6 & $\begin{array}{l}\text { Austenitization at } 965^{\circ} \mathrm{C} \\
\text { during } 45 \text { min., tempering at } \\
565^{\circ} \mathrm{C} \text { during } 90 \text { min and } \\
\text { DCT at }-190^{\circ} \mathrm{C} \text { for } 20 \text { hours }\end{array}$ \\
\hline III & 6 & $\begin{array}{l}\text { Austenitization at } 965^{\circ} \mathrm{C} \\
\text { during } 45 \text { min., tempering at } \\
565^{\circ} \mathrm{C} \text { during } 90 \text { min., DCT at } \\
-190^{\circ} \mathrm{C} \text { for } 20 \text { hours and } \\
\text { tempering at } 565^{\circ} \mathrm{C} \text { for } 90 \\
\text { min. }\end{array}$ \\
\hline IV & 6 & $\begin{array}{l}\text { Austenitization at } 1065^{\circ} \mathrm{C} \\
\text { during } 45 \mathrm{~min} \text {., tempering at } \\
565^{\circ} \mathrm{C} \text { during } 90 \mathrm{~min} \text {. }\end{array}$ \\
\hline V & 6 & $\begin{array}{l}\text { Austenitization at } 1065^{\circ} \mathrm{C} \\
\text { during } 45 \text { min., tempering at } \\
565^{\circ} \mathrm{C} \text { during } 90 \text { min and } \\
\text { DCT at }-190^{\circ} \mathrm{C} \text { for } 20 \text { hours }\end{array}$ \\
\hline VI & 6 & $\begin{array}{l}\text { Austenitization at } 1065^{\circ} \mathrm{C} \\
\text { during } 45 \text { min., tempering at } \\
565^{\circ} \mathrm{C} \text { during } 90 \text { min., DCT at } \\
-190^{\circ} \mathrm{C} \text { for } 20 \text { hours and } \\
\text { tempering at } 565^{\circ} \mathrm{C} \text { for } 90 \\
\text { min. }\end{array}$ \\
\hline
\end{tabular}

The austenitization process was conducted at $965^{\circ} \mathrm{C}$ and $1065^{\circ} \mathrm{C}$ into a tube furnace KK $170 \mathrm{SO}$ 1059 , with automatic temperature control, and accuracy of $0.5 \% / 100 \mathrm{ppm} /{ }^{0} \mathrm{C}$.
The quenching was carried out in automotive oil SAE $20 \mathrm{~W}-50$ at room temperature $\left(32^{\circ} \mathrm{C}\right)$ fallowed by tempering.

The DCT was accomplished at Kryos Technology at Brasilia University. The DCT treatment consisted of slow cooling of oil-quenched specimens to $-190^{\circ} \mathrm{C}$. In order to avoid thermal shocks from rapid cooling and heating, the specimens were cooled down and heated up slowly, to and from the cryogenic temperature $\left(-190^{\circ} \mathrm{C}\right)$. This treatment was used directly after oil quenching from the austenitization temperature and was followed by tempering.

\section{Micro-abrasive wear test}

The micro-abrasive wear test was conducted in a micro-abrasive machine CALOWEAR in the Tribology and Materials Lab at Uberlandia University, Brazil. First of all the samples were embedded at polymeric resin attending the surface parallelism, followed by surface polish using diamond abrasive paste. Was used $\mathrm{SiC}$ as abrasive supply in the micro abrasive wear test, in $10 \%$ weight vs. $90 \%$ distilled water proportion. The dripping of mud was fixed and kept in 3 drops/sec. The abrasive was kept in constant mixing; avoiding the silicon carbide precipitation. The micro-abrasive wear test conducted was the free rotating ball one. In this test the normal force is defined by the own weight of the sphere besides tilting the sample and its relative position to the motor shaft (Silva, 2003). Penetration depth (h) of the test sphere and the volume of the crater wear $(\mathrm{V})$ are calculated athwart as follows:

- Penetration depth of the test sphere (h):

$$
h=12.70-\sqrt{161.29-0.25 d^{2}}
$$

Volume of the crater wears $(\mathbf{V})$ :

$$
\mathrm{V}=\pi\left[12.70 \mathrm{~h}^{2}-\frac{h^{3}}{3}\right]
$$

Equations (1) and (2) were developed for a $25.4 \mathrm{~mm}$ diameter sphere (Baptista, Ferreira and Pinto, 2000), (Rutherford and Hutchings, 1996), (Hutchings, 1998) and (Rutherford and Hutchings, 1997). For the tests were defined a charge between 0.4 and $0.6 \mathrm{~N}$ controlled by a charge cell coupled to the sample port that has horizontal displacement and one can also adjust the inclination relative to the driveshaft. The sphere used was made of steel AISI 52100. The driveshaft rotation speed was controlled on $150 \mathrm{rpm}$. The wear calotte measure was done every 5 min until the steady state wear. In the Fig. 1 one can observe a diagram of the micro-abrasive wear test. 


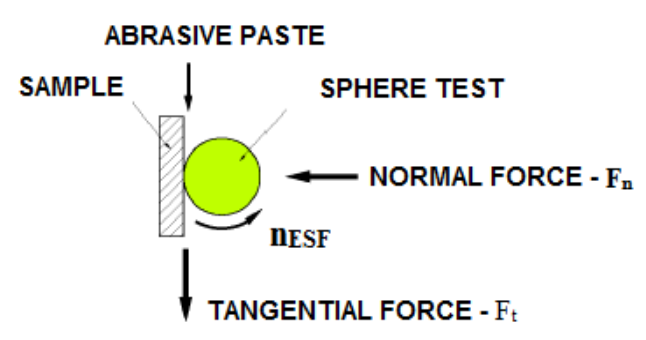

Figure 1. Micro-abrasive wear test diagram.

\section{Brinell Hardness}

The hardness analysis was made in "HPO-250" Brinell hardness tester in the materials metallographic lab on the Technology Department at The University of Brasilia. The tests were done with $187.5 \mathrm{Kg}$ charge, $15 \mathrm{sec}$ of application of the force and $2.5 \mathrm{~mm}$ sphere indenter diameter.

\section{RESULTS AND DISCUSSIONS}

\section{Metallographic Analysis and Austenitization Temperature Influence}

For cycle I (Figure 2a) the steel CA6NM presented martensitic structure and parallel slat with same orientation, forming blocks. There is small amount of retained austenite in this case. For cycle II (Figure 2b) it is possible to identify the DCT effect. Presented microstructure formed thin needles of martensitic and homogeneous distribution. Simultaneously it is possible to identify thin tracks of retained austenite at martensite boundary grains.

In Figure 2a and Figure 3a one can identify characteristics quenching-and-temper martensite needles, in steels like this one. It's possible to identify the needle-size differences in the microstructure grains for the different austenitization temperatures. Moreover, martensite needles distribution and austenitic grain size difference are found.

For cycle III is shown at Figure 2c martensitic needles and large quantity of retained austenite in the martensitic boundary grains homogenously distributed.

The micro-structure shown in Figure 2a, the martensite it's arranged in parallel laths with the same crystallographic distribution forming blocks. In this micrograph it's not possible identify retained austenite. Already in micrograph, Figure $2 \mathrm{~b}$ one can saw the cryogenic treatment effect. Observe the fine needles of martensite arranged homogeneously. Also are observed thin traces of retained austenite between the boundaries of the sets of martensite. In the micrograph of Figure 2c, as in cycle II, are clearly recognizable the martensite needles and the highest amount of retained austenite in the boundaries of martensite, homogeneously distributed.
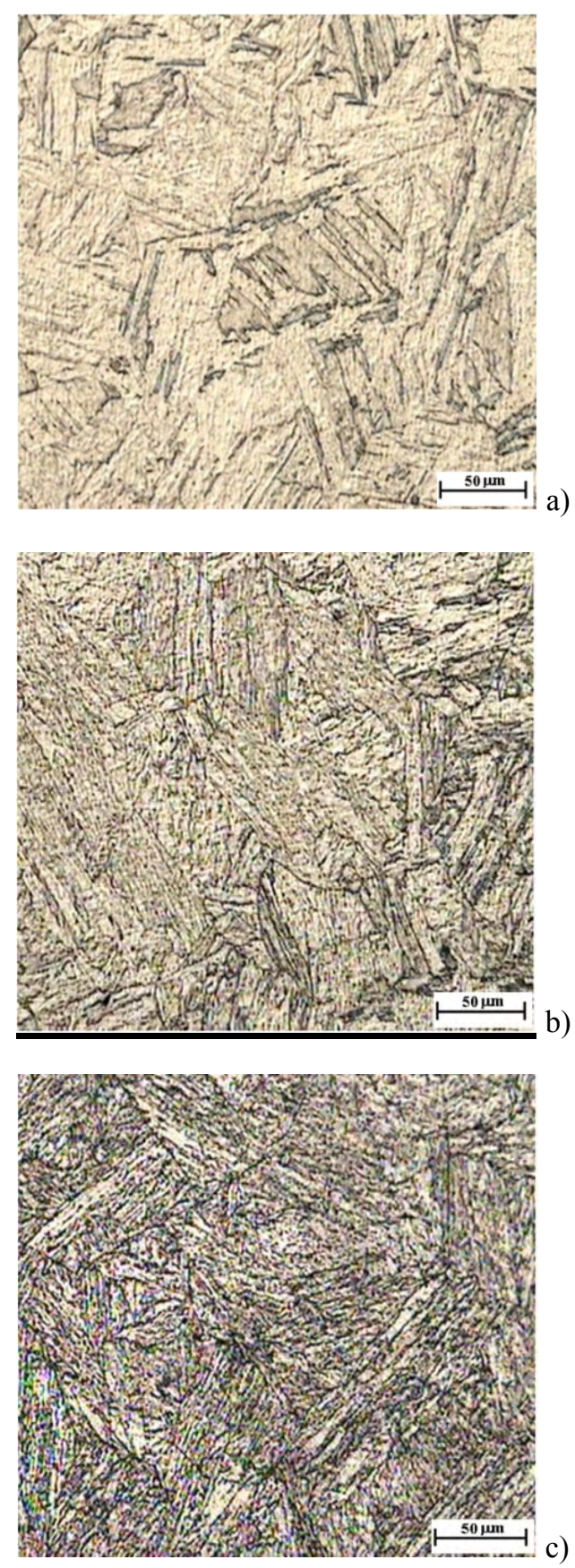

Figure 2. a)Cycle I (A) at $965^{\circ} \mathrm{C},(\mathrm{T})$ at $565^{\circ} \mathrm{C} .200$ X., b) Cycle II . (A) at $965^{\circ} \mathrm{C},(\mathrm{T})$ at $565^{\circ} \mathrm{C}$ and DCT at $-190^{\circ} \mathrm{C}$, for 20 hours. 200 X., b) Cycle III .(A) at $965^{\circ} \mathrm{C},(\mathrm{T})$ at $565^{\circ} \mathrm{C}$, DCT at $-190^{\circ} \mathrm{C}$, for 20 hours, and $(\mathrm{T})$ at $565^{\circ} \mathrm{C}$.

Although it is not possible to quantify neither martensite laths (the thickness and length), nor their blocks and packages (which are important parameters that influence the mechanical properties) It's possible to identify that the martensite needles of the austenitized samples at $1065^{\circ} \mathrm{C}$ (Figure $3 \mathrm{~b}$ and Fig. $3 \mathrm{c}$ ) are larger and coarser when compared with the samples austenitized at $965^{\circ} \mathrm{C}$. 


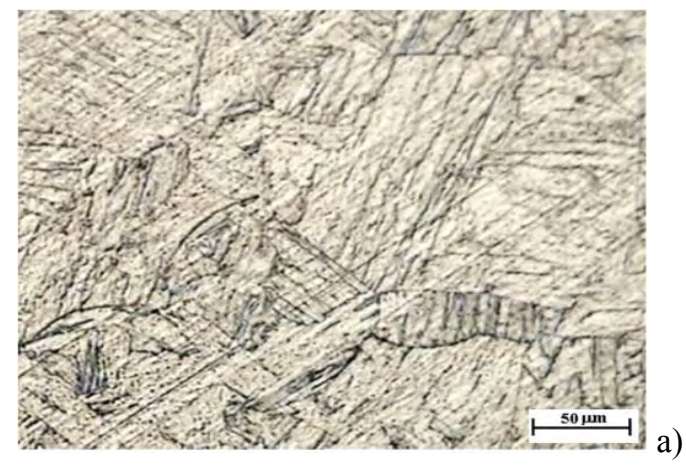

(Krauss, 1999 and Petty, 1970). This relationship it's possible because within the packets of martensite exists the same crystallographic orientation similar to what occurs with the grains of the polycrystalline material. The relationship type Hall-Petch, founded in the polycrystalline materials, that combine the strength of the yield strength $\left(\sigma_{\mathrm{Y}}\right)$ with the average size of the package of martensite $(\bar{D})$, show to be valid in relation to the size of packets, as follows, which is known as Norström equation (Pereira, 2000).

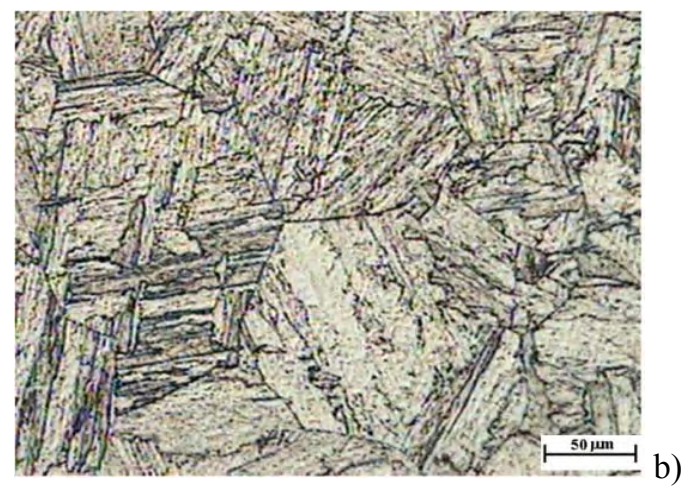

$$
\begin{aligned}
& \sigma_{y}=\sigma_{0}+\sigma_{1}+K_{y}(\bar{D})^{-\frac{1}{2}}+K_{S} d^{-\frac{1}{2}}+ \\
& \text { a.G.b[} \left.\rho_{0}+K(\% C)+\frac{2 \theta}{b d}\right]^{\frac{1}{2}}
\end{aligned}
$$

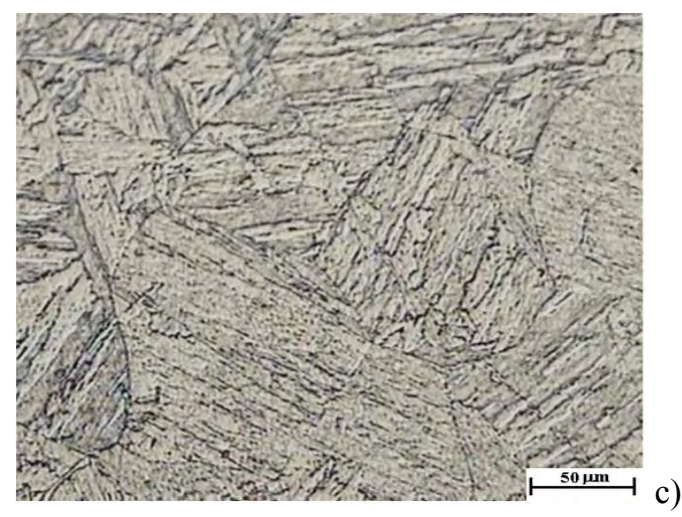

Figure 3. a) Cycle IV. (A) at $1065^{\circ} \mathrm{C},(\mathrm{T})$ at $565^{\circ} \mathrm{C}$. 200 X., b) Cycle V. (A) at $1065^{\circ} \mathrm{C},(\mathrm{T})$ at $565^{\circ} \mathrm{C}$ and DCT at $-190^{\circ} \mathrm{C}$, for 20 hours. $200 \mathrm{X}$., c) Cycle VI. (A) at $1065^{\circ} \mathrm{C},(\mathrm{T})$ at $565^{\circ} \mathrm{C}, \mathrm{DCT}$ at $-190^{\circ} \mathrm{C}$, for 20 hours, and (T) at $565^{\circ} \mathrm{C}$.

When the austenitize temperature is high there is an austenitic grain size and carbide dissolution increase. After martensite transformation, the primary austenite size will determine important martensite characteristics like the packages and blocks size (Petty, 1970), which will have direct influence in the mechanicals properties. The smaller austenite grains the smaller martensite packages and blocks resulting in a more refine martensite. Thus, the greater wear resistance and other parameters of mechanical strength because of grain refining works the same way as in the polycrystalline material, increasing the resistance of the material. This effect of refinement of martensite is also found in quenching material where:

$\sigma 0 \quad$ frictional stress of iron $\alpha$

$\sigma 1$ solid solution hardening due to $\mathrm{Mn}$

$K_{y}(\bar{D})^{-\frac{1}{2}}$ correlation type of Hall-Petch to the martensite packet size $(\bar{D})$ and $K_{y}$ varies depending on the content of $\mathrm{Ni}$ and $\mathrm{Mn}$ steel

$$
\begin{array}{ll} 
& \text { martensite width }(\mathrm{d}) \\
\mathrm{a} & \text { it's a constant }=0.7 \\
\mathrm{G} & \text { shear modulus of steel } \\
\mathrm{b} & \text { Burgers's vector }
\end{array}
$$$$
K_{S} d^{-\frac{1}{2}} \quad \text { correlation type Hall-Petch for laths }
$$

$\rho_{0}+K(\% C)$ represent a linear relationship

between the density of dislocations within the laths and the percentage of carbon steel;

\section{$\frac{2 \theta}{b d}$}

contribution to the dislocation density of

low angle boundaries, where: $\theta$ is the degree of disorientation among the contours of the laths.

When analyzing the micrographs in this work in light of the primary austenite grain, one observe that in samples treated at higher austenitizing temperature (Figure $3 \mathrm{~b}$ and Fig. 3c) grains of larger sizes and better defined that in samples treated at $965^{\circ} \mathrm{C}$ were formed Figure 2. The austenitic grain boundary is perfectly defined by retained austenitic. Twice the amount of austenite grains was found in Fig. 2a (20 austenitic grains) compared to Fig. 3a (10 austenitic grains). Image processing using Image-pro Plus 6.3 was used.

Comparing vertically cycle I and IV micrograph results, which weren't cryogenically treated, one can appreciate that in cycle IV exist more refined martensite needles than in cycle I; showing a 
structure more similar to that obtained in cycle II. Building on the scale of the photomicrographs, which is the same for all images, one can appreciate the differences between sizes of needles and the grain sizes for the different treatments. When analyzed Figure $2 b$ and Figure $3 b$ striking differences are observe when analyzed the refinement of the martensite, the size and distribution of packaged needles of martensite, the amount of retained austenite and the austenitic grain size.

Analyzing the micrograph in Figure 2c and Figure $3 c$ more striking difference are found. In cycle III was obtained a more refined martensite, forming a big tangle of small packages within the austenite grain while in cycle VI one can found large austenitic grain composed of coarse needles of martensite forming big blocks.

Since the microstructure of the cycle V, VI and I are similar, with distributed parallel slats forming blocks. This shows that for steel CA6NM treated to higher austenitizing temperatures $\left(1065^{\circ} \mathrm{C}\right)$ the cryogenic treatment does not influence the type of martensite to obtain.

The austenitization temperature has a direct influence over the microstructure. It affects the elements diffusion and the precipitates stability. The austenitic grain size and precipitate solubilized are the principal variables of the microstructure modifications susceptible to micro-structural changes.

According to Meng et al. reports (Meng et al., 1994) the higher martensitic deformation energy promoted by the continuous and deep cooling procedure, increases its instability, and probably, affects the microstructure dislocation during the iron crystalline parameters contractions Carbon atoms will be forced out off its positions where they will form a transition carbide structure with submicroscopic dimensions. This structure formed at the martensitic matrix will form thin stables carbide clusters when return to room temperature or tempering.

\section{Hardness Analysis}

With the results of these tests, presented in Table 2, it is observed for the samples austenitized at $1065^{\circ} \mathrm{C}$, after application of different heat treatment cycles, no significant changes in hardness of the material. In cycle IV decreased $\approx 6 \mathrm{HB}$ and in cycle $\mathrm{VI}$ increased $\approx 2 \mathrm{HB}$. According to the standard delivery TDS Technical Specification for Martensitic Stainless Steel ASTM A 743 CA6NM contained in Appendix A should be $\leq 285$ Brinell hardness. The samples treated at $965^{\circ} \mathrm{C}$ suffered a modest variation, cycle II increase hardness in the range of $12 \mathrm{HB}$, approximately 4\% (277.2 HB) and Cycle III increased approximately $14 \mathrm{HB}$, about $8 \%$ (287.8 HB) compared with cycle I (reference cycle) which recorded a Brinell hardness $265.0 \mathrm{HB}$. This material is heat treated in the manufacturing process, where it receives quenching and tempering.

Table 2. Hardness measurements results.

\begin{tabular}{|c|c|c|c|}
\hline & \multicolumn{3}{|c|}{ Austenitization at 965 C } \\
\hline & Cycle I & Cycle II & Cycle III \\
\hline $\begin{array}{c}\text { Mean Value } \\
\text { Brinell } \\
\text { Hardness (HB) }\end{array}$ & 265 & 277.2 & 287.8 \\
\hline $\begin{array}{c}\text { Rockwell C } \\
\text { Hardness } \\
\text { Equivalence }\end{array}$ & 26.2 & 29 & 30.2 \\
\hline \multicolumn{3}{|c|}{ Austenitização a 1065 C } \\
\hline $\begin{array}{c}\text { Mean Value } \\
\text { Brinell } \\
\text { Hardness (HB) }\end{array}$ & 267.2 & 261.4 & 269.6 \\
\hline $\begin{array}{c}\text { Rockwell C } \\
\text { Hardness } \\
\text { Equivalence }\end{array}$ & 26.5 & 25.6 & 28.1 \\
\hline
\end{tabular}

Analyzing the results of the coefficient of variation can be verified that the results of the measurements showed a homogeneous behavior, concluding that the tests had a high repeatability. Analyzing the results of the first group austenitized at $965^{\circ} \mathrm{C}$ can be stated that there were modest increases in hardness, because the increments are larger than the coefficient of variation. When studied the results of the samples austenitized at higher temperature $\left(1065^{\circ} \mathrm{C}\right)$ is observed that a $2 \%$ hardness decrease in cycle V (261.4 HB), and $0.9 \%$ increase in cycle VI (269.6 HB), are lower than the dispersion of the measurements, so we can say that there was no change in hardness of these specimens compared with its reference cycle (cycle IV), which registered $267.2 \mathrm{HB}$.

Analyzing the results in Table 2 was found a small difference in hardness between samples heated at $965^{\circ} \mathrm{C}$ untreated cryogenically (cycle I) and those that were treated (cycle II and III).

As can be seen in the first cycle the hardness value is lower about 5 to $7 \%$. One can attribute this variation to the change experienced by the microstructure, possibly through the actions of DCT. The microstructure changed from martensite needles arranged in parallel forming blocks Figure $2 \mathrm{a}$ to fine needles of martensite uniformly distributed Figure $2 b$ and Fig. 2c.

Another interesting factor, even if not appearing in the micrographs, it is possible precipitation of micro-carbides, dispersed in a soft matrix. These carbides, being harder than the matrix, can negatively influence the measurement, recording a hardness value less than the real, but it would have a positive influence on the wear resistance.

Variations in hardness observed in cycles I and II, resulting from cryogenic and tempering treatment were compatible with results reported by Collins and Barron (Barron, 1974 and 1980, and Collins, 1998), 
which indicated a maximum increase of hardness for cryogenically treated samples no larger than two points on the Rockwell $\mathrm{C}$ scale compared to conventional treatment.

\section{Micro-Abrasive Wear.}

Figure 2 shows the wear coefficient and removed volume of material identifying the started point of permanents wear regime (a). These regime data are essential for the results analysis.

The results of micro-abrasive wear resistance tests for martensitic stainless steel A 743 grade CA6NM allowed the evaluation of effect of different heat treatment, showing mainly the DCT effect in the wear resistance of this material.

At curves depicted at Fig. $4 \mathrm{a}$ is possible to identify the wear behavior for cycle I and cycle III at samples austenitize at $965^{\circ} \mathrm{C}$. For cycle I (without DCT), the wear resistance coefficients values were near to standard conditions, observed at as received samples.

For cycle II, conventional heat treatment fallowed by DCT, lower wear resistance coefficient was observed, reaching approximately $31 \%$ to the conventional treatment. In this case there was an increase of wear resistance.

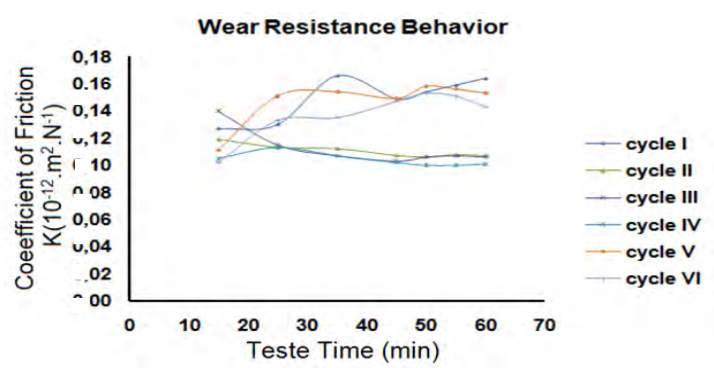

a)

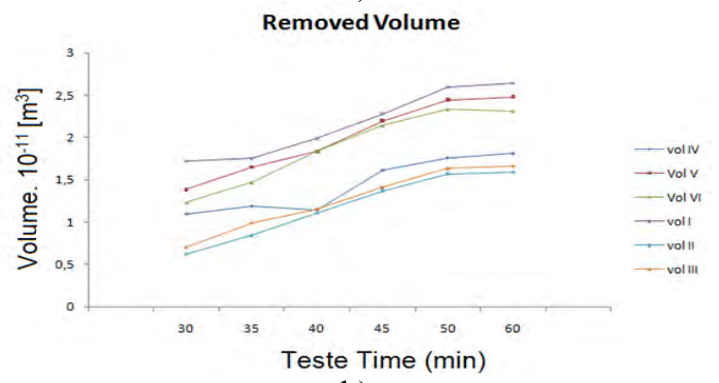

b)

Figure 4. a) Comparison of wear coefficient and b) removed volume of material. Cycle I. (A) at $965^{\circ} \mathrm{C}$,

(T) at $565^{\circ} \mathrm{C}$; Cycle II. (A) at $965^{\circ} \mathrm{C}$; (T) at $565^{\circ} \mathrm{C}$ and DCT at $-190^{\circ} \mathrm{C}$, for 20 hours; Cycle III. (A) at $965^{\circ} \mathrm{C},(\mathrm{T})$ at $565^{\circ} \mathrm{C}$, DCT at $-190^{\circ} \mathrm{C}$, for 20 hours, and (T) at $565^{\circ}$; Cycle IV. (A) at $1065^{\circ} \mathrm{C}$, (T) at $565^{\circ} \mathrm{C}$; Cycle V. (A) at $1065^{\circ} \mathrm{C},(\mathrm{T})$ at $565^{\circ} \mathrm{C}$ and DCT at $-190^{\circ} \mathrm{C}$, for 20 hours; Cycle VI. (A) at $1065^{\circ} \mathrm{C},(\mathrm{T})$ at $565^{\circ} \mathrm{C}, \mathrm{DCT}$ at $-190^{\circ} \mathrm{C}$, for 20 hours, and $(\mathrm{T})$ at $565^{\circ} \mathrm{C}$.

Cycle III, conventional heat treatment fallowed by DCT fallowed by tempering, showed a decrease of wear coefficient of about $29 \%$, showing a wear resistance improvement but slightly slower than cycle II. Cycles II and III showed important modifications in comparison with cycle I (reference cycle). There was in this case reduction at removed volume of material during the test.

Figure $4 \mathrm{~b}$ shows comparative results of removed volume of material for the three heat treatment cycles. Cycles II and III shows lower removal of material, these microstructures have undergone modifications that allowed increase of the micro-abrasive wear resistance. Meng in (Meng et al., 1994), whose determine the carbides micromechanism precipitation at cryogenics temperatures, yielded that the $\mathrm{Fe}_{2} \mathrm{C}$ submicroscopic carbides clusters formation occurs from the martensitic tetragonal structure transformation, allowing an orthorhombic structure formation of precarbides. It is therefore reasonable to infer that a higher quantity of orthorhombic martensite make possible the growing of higher quantity of clusters during the DCT, resulting at higher thin carbides precipitation.

Although residual austenite transforms instantaneously into a tetragonal structure of martensite when cooled near the Mf temperature of steel, previous work (Meng et al., 1994) confirmed that these martensite on the micro-structure do not respond to the DCT in the same way that those coming from quenching. According to Pen-Li Yen (Yen, 1997), the martensite formed during DCT has a net parameter proportion c/a from the martensitic tetragonal structure, higher than this parameter for quenching martensite. These different structures can present different transformation capacities to form $\eta$ carbides.

\section{CONCLUSIONS}

The micrographic analyses allowed the verification of DCT influence at the $965^{\circ} \mathrm{C}$ austenitizing samples. It was demonstrated that after DCT there is a transformation of martensitic structure and parallel slat with same orientation, coming from conventional treatment- to a little parallel blocks and almost parallel thin needles defining austenitic grains. Tracks of retained austenitic forms grain boundaries. Taking into account that a continuous cooling promotes a martensitic energy transformation, increasing its instability and, possibly, affecting its dislocation structure at the same time that the iron crystalline net supported atomics contractions, the carbon atoms will be expelled from its position forming the structure of submicroscopic transition carbide. These structures in the martensitic matrix will be act like nucleus for the thin stable carbides formation (Meng et al., 1994).

Considering the higher amount of martensite and lower quantity of retain austenite in the samples 
austenitize at lower temperature $\left(965^{\circ} \mathrm{C}\right)$, the DCT had better response in these samples when compared with those austenitize at $\left(1065^{\circ} \mathrm{C}\right)$. For this higher austenitizing temperature there is higher amount of retained austenite that difficult martensitic transformation. According to Pen-Li Yen (Yen, 1997), the martensite formed during DCT has a net parameter proportion c/a from the martensitic tetragonal structure higher than the c/a from quenching martensite, showing that these different structures can present different transformation capacities to form $\eta$-carbides.

\section{REFERENCES}

Newman, R. C., 2001, Understanding the Corrosion of Stainless Steel, Corrosion, Vol. 57, No. 12, pp. 1030-1041.

Barron, R. F., 1982, Cryogenic Treatments of Metals to Improve Wear Resistance, Cryogenics, Vol. 22, No. 8, pp. 409-413.

Barron, R. F., and Thompson, R. H., 1990, Effect of Cryogenic Treatment on Corrosion Resistance, Advances in Cryogenic Engineering, Vol. 36, pp. 1375-1379.

Meng, F., Tagashira K., Azuma, R., and Sohma, H., 1994, Role of Eta-Carbide Precipitations in the Wear Resistance Improvements of Fe-12Cr-Mo-V$1.4 \mathrm{C}$ Tool Steel by Cryogenic Treatment, ISIJ International, Vol. 34, No. 2, pp. 205-210.

Silva Jr., W. M., 2003, Efeito da Pressão de Compactação e Tamanho do Pó de Ferro na MicroAbrasão do Ferro Sinterizado Oxidado a Vapor, Master Thesis, Universidade Federal de Uberlândia, Uberlândia, MG. (in Portuguese)

Baptista, A. M., Ferreira, J., and Pinto, N., 2000, Ensaios de Micro-Abrasão por Esfera Rotativa, in: $7 a$ Jornada Portuguesa de Tribologia, Porto, Portugal. (in Portuguese)

Rutherford, K. L., and Hutchings, I. M., 1997, Theory and Application of Micro-Scale Abrasive Wear Test, Journal or Testing and Evaluation, Vol. 25, No. 2, pp. 250-260.

Hutchings, I. M., 1998, Abrasive and Erosive Wear Tests for Thin Coatings: a Unified Approach, Tribology International, Vol. 31, No. 1-3, pp. 5-15.

Rutherford, K. L., and Hutchings, I. M., 1996, A Micro-Abrasive Wear Test, with Particular Application to Coated Systems, Surface and Coatings Technology, Vol. 79, No. 1-3, pp. 231-239.

Petty, E. R., 1970, Martensite: Fundamentals and Technology, Longman Group Ltd, London. p11, pp. 119-136 and 174 .

Pereira, S. A., 2000, Desenvolvimento de Procedimento de Reparo por Soldagem em Aços Inoxidáveis Martensíticos com Metal de Adição Similar sem TTP, Master Thesis, Universidade Federal de Santa Catarina, Florianópolis, SC. (in Portuguese)

Krauss, G., 1999, Martensite in Steel: Strength and Structure, Materials Science and Engineering A, Vol. 273-275, pp. 40-57.

Barron, R. F., 1974, Cryogenic Treatment Produces Cost Saving for Slitter Knives, Tappi Journal, Vol. 57, No. 5, pp. 137-139.

Barron, R. F., 1980, Cryogenic Treatment of AISI T8 and C1045 Steels, Advances in Cryogenic Engineering Materials, Vol. 26, pp. 171-179.

Collins, D. N., 1998, Cryogenic Treatment Tool Steels, Advanced Materials and Processes, Vol. 154, No. 6, pp. 23-29.

Yen, P. L., 1997, Formation of Fine EtaCarbides in Special Cryogenic and Tempering Process Key to Improve Properties of Alloy Steels, Industrial heating, Vol. 14, pp. 40-44. 